[Denpun Kagaku, Vol. 40, No. 1, p. 1〜5 (1993)]

\title{
Synthesis of Glucosylxyluloside Using Sucrose Phosphorylase
}

\author{
Hideki TAKahashi,* Kozo HaRa,* Hitoshi Hashimoto,* \\ Takashi SASAKI** and Hajime TANIGUCHI**,*** \\ * Carbohydrate Research Laboratory, Ensuiko Sugar Refining Co., Ltd. \\ (13-46, Daikoku-cho, Tsurumi-ku, Yokohama 230, Japan) \\ ** National Food Research Institute \\ (2-1-2, Kannondai, Tsukuba 305, Japan) \\ *** Present Address, Iwate Prefecture Brewing and Food Research Institute \\ (26, Tsushida, Morioka 020, Japan)
}

\begin{abstract}
Synthesis of glucosylxyluloside (Glc-Xul) by the action of sucrose phosphorylase [EC 2.4. 1.7] from Leuconostoc mesenteroides was studied. In the transfer reaction using equimolar amount of $\alpha$-D-glucose-1-phosphate (G-1-P) and D-xylulose, about $25 \%$ of D-xylulose was converted into Glc-Xul, whereas only $17 \%$ of $\mathrm{D}$-fructose was converted into sucrose when $\mathrm{D}$-fructose was used instead of D-xylulose. In the transfer reaction using equimolar amount of sucrose and $\mathrm{D}$-xylulose, more than $60 \%$ of $\mathrm{D}$-xylulose was converted into Glc-Xul. It was found that more than $80 \%$ of added D-xylulose was converted into Glc-Xul when the molar ratio of sucrose to $\mathrm{D}-\mathrm{xylulose}$ was increased to 3 .
\end{abstract}

Sucrose phosphorylase [EC 2.4.1.7] catalyzes two types of transfer reaction. One is a transfer of D-glucose from G-1-P to an acceptor sugar (Eq. (1)). Synthesis of sucrose from G-1-P and $\mathrm{D}$-fructose is the most popular example of this reaction. Another is a transfer of D-glucose from sucrose to an acceptor sugar (Eq. (2)).

$$
\begin{aligned}
& \mathrm{G}-1-\mathrm{P}+\mathrm{Acp} *=\mathrm{Glc}-\mathrm{Acp}+\mathrm{Pi}^{* *} \\
& \mathrm{Suc}^{* * *}+\mathrm{Acp}=\text { Glc-Acp }+\mathrm{Fru}^{* * * *}
\end{aligned}
$$

This enzyme was found in microorganisms such as Pseudomonas saccharophila, ${ }^{1} P$. putrefaciens, ${ }^{2)}$ Clostridium pasteurinum, ${ }^{3)}$ Acetobacter xylinum, ${ }^{4)}$ Pullularia pullulans ${ }^{5}$ and Leuconostoc mesenteroides. ${ }^{6)}$ The enzyme from $P$. saccharophila utilizes D-fructose, ${ }^{11} \mathrm{~L}$ sorbose, ${ }^{7)} \mathrm{D}$-xylulose, ${ }^{7)} \mathrm{L}$-ribulose, ${ }^{8)} \mathrm{L}$-arabinose ${ }^{8)}$ and D-rhamnulose ${ }^{9)}$ as an acceptor sugar and produces $\alpha$-D-glucopyranosyl- $(1 \rightarrow 2)$ - $\beta$-D-fructofuranoside (= sucrose), $\alpha$-D-glucopyranosyl- (1 $\rightarrow 2$ )- $\alpha$-L-sorbofuranoside(Glc-Sor), $\alpha$-D-glucopyranosyl- $(1 \rightarrow 2)-\beta$-D-xylulofuranoside (glucosylxyluloside $=$ Glc-Xul), $\alpha$-D-glucopyranosyl- $(1 \rightarrow 2)$ $\alpha$-L-ribulofuranoside, $\quad \alpha$-D-glucopyranosyl- $(1 \rightarrow$ 3 )-L-arabinopyranose (Glc-Ara) and $\alpha$-D-glucopy-

Acp* =acceptor, $\mathrm{Pi}^{* *}=$ inorganic phosphate, Suc*** $=$ sucrose, $\mathrm{Fru}^{* * * *}=\mathrm{D}$-fructose. ranosyl-( $1 \rightarrow 2)$ - $\beta$-D-rhamnulofuranoside, respectively, in the transfer reaction using G-1-P. The enzyme from $P$. saccharophila was purified and its physicochemical and catalytic properties were extensively studied by Silverstein et $a l .^{10-12)}$

In a hope to develop a useful application of hemicellulose we have studied the preparation of D-xylose from agricultural wastes and its efficient conversion to $\mathrm{D}$-xylulose, and further tried to convert this $\mathrm{D}$-xylulose into Glc-Xul, a sucrose analogue, using sucrose phosphorylase. This compound is expected to show slightly different but important, from the standpoint of application, properties from those of sucrose.

It was reported that L. mesenteroides produced higher amount of sucrose phosphorylase per cells than P. saccharophila and P.putrefaciens. ${ }^{13)}$ An efficient method to convert $\mathrm{D}$ xylulose into Glc-Xul using the enzyme preparation obtained from L. mesenteroides will be described in this paper.

\section{MATERIALS AND METHODS}

Microorganism. Leuconostoc mesenteroides 
ATCC 12291 was purchased from American Type Culture Collection.

Materials. D-Xylulose was prepared from $\mathrm{D}$-xylose by the action of xylose isomerase and separated from D-xylose by an ion exchange chromatography. Phosphoglucomutase and glucose-6-phosphate dehydrogenase were purchased from Boehringer Mannheim Yamanouchi Co. Other saccharides and chemicals were purchased from commercial sources.

Preparation of sucrose phosphorylase. The microorganism was cultivated semi-anaerobically according to the method of Vandamme et al. ${ }^{14)}$ Cells were harvested after $15 \mathrm{hr}$, at early stationary phase, by centrifugation, freeze-dried and stocked at $-20^{\circ} \mathrm{C}$.

These cells were used as an enzyme source in some experiments. The freeze-dried cells were suspended $(20 \mathrm{mg} / \mathrm{ml})$ in $10 \mathrm{mM}$ Tris-maleate buffer ( $\mathrm{pH}$ 6.7) and sonicated with SONIFIER CELL DISRUPTER 350 (Branson Sonic Power Co.) under cooling condition at $4^{\circ} \mathrm{C}$. The resultant suspension was centrifuged and the obtained supernatant was brought to $80 \%$ saturation by adding solid ammonium sulfate. After standing overnight at $4^{\circ} \mathrm{C}$, the precipitate formed was collected by centrifugation, dissolved in $10 \mathrm{mM}$ Tris-maleate buffer (pH 6.7) and dialyzed overnight against the same buffer. The obtained solution was used as sucrose phosphorylase preparation in most of the experiments.

Assay of enzymatic activity. The enzymatic activity was routinely assayed in a reaction mixture containing $0.1 \mathrm{M}$ sucrose, $0.1 \mathrm{M} \mathrm{K}_{2}$ $\mathrm{HPO}_{4}, 0.1 \mathrm{M} \mathrm{KH}_{2} \mathrm{PO}_{4}, 0.2 \mathrm{M} \mathrm{NaHCO}_{3}, 0.1 \mathrm{M}$ $\mathrm{KF}$ ( $\mathrm{pH}$ 6.7) and a suitable amount of enzyme solution. The reaction mixture was incubated at $37^{\circ} \mathrm{C}$ for $30 \mathrm{~min}$ and boiled for $3 \mathrm{~min}$ to inactivate the enzyme, and the amount of G-1-P produced was determined by the phosphoglucomutase-glucose-6-phosphate dehydrogenase method. ${ }^{15)}$ One unit (U) of sucrose phosphorylase was defined as the amount of enzyme that produced $1 \mu \mathrm{mol}$ of G-1-P per min under the above conditions.

When the transfer reaction using G-1-P and an acceptor sugar was run, the amount of released inorganic phosphate $(\mathrm{Pi})$ was measured according to the method of Lowry and Lopetz. ${ }^{16)}$
Synthesis of disaccharides. Except where otherwise stated, the reaction mixture for disaccharide synthesis contains $50 \mathrm{~mm}$ of G-1-P or sucrose as a glucosyl donor, $50 \mathrm{mM}$ acceptor sugar and suitable amount of the enzyme in $50 \mathrm{~mm}$ Tris-maleate buffer ( $\mathrm{pH}$ 7.0). The reaction was carried out at $37^{\circ} \mathrm{C}$, and aliquots were withdrawn at intervals, boiled for $3 \mathrm{~min}$ to inactivate the enzyme, deionized and subjected to high performance liquid chromatography.

High performance liquid chromatography (HPLC). HPLC was carried out with TRIROTOR SR-2 (Japan Spectroscopic Co., Ltd.) equipped with an RI detector. MCI GEL CK08EC column $(8 \times 300 \mathrm{~mm}$, Mitsubishi Kasei Co.) was used at $65^{\circ} \mathrm{C}$ with the mobile phase of water at a flow rate of $0.6 \mathrm{ml} / \mathrm{min}$ for routine analysis. Sample solutions were deionized by adding suitable amount of Amberlite IR120B and IRA-93, and the resultant supernatants $(20 \mu \mathrm{l})$ were injected. The amount of each disaccharide was calculated using standard curve of sucrose. The yield of disaccharide formed was defined by the following equation,

$$
\text { Yield }(\%)=\frac{\text { amount (mol) of disaccharide }}{\text { produced }} \begin{gathered}
\text { amount }(\mathrm{mol}) \text { of added acceptor } \\
\times 100
\end{gathered}
$$

\section{RESULTS AND DISCUSSION}

Preparation of crude sucrose phosphorylase solution. At first the possibility of using dry cells as an enzyme for sucrose synthesis was studied. The cells were incubated with $50 \mathrm{mM}$ each of G-1-P and D-fructose. D-Fructose in the reaction mixture decreased continuously and disappeared almost completely. Sucrose started to accumulate at first, but its accumulation stopped at a concentration of only $7 \mathrm{mM}$. Instead, large amount of mannitol was produced throughout the incubation. This is probably because of the presence of mannitol dehydrogenase, which converts $\mathrm{D}$-fructose into mannitol.

To avoid the formation of mannitol, the dry cells were then sonicated and the solubilized enzyme preparation was concentrated by $80 \%$ saturated ammonium sulfate precipitation. As shown in Fig. 1, this preparation did not form mannitol and, therefore, was used as sucrose 


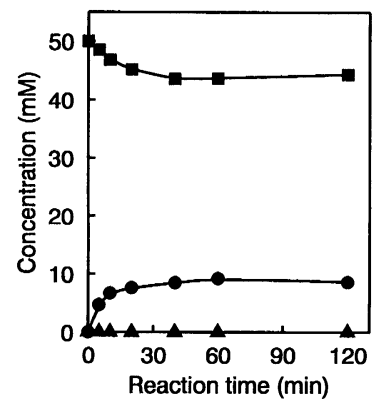

Fig. 1. Sucrose synthesis by the enzyme preparation.

Fifty $\mathrm{mM}$ each of $\mathrm{G}-1-\mathrm{P}$ and $\mathrm{D}$-fructose were incubated with the enzyme preparation $(5.5 \mathrm{U} / \mathrm{ml})$ in $50 \mathrm{mM}$ Tris-maleate buffer $(\mathrm{pH} 7.0)$ at $37^{\circ} \mathrm{C}$. For other details see MATERIALS AND METHODS.

, Sucrose ; $\boldsymbol{\square}$, D-Fructose ; $\boldsymbol{\Delta}$, Mannitol.

Table 1. Relative initial rates of disaccharide formation from various acceptor sugars.

\begin{tabular}{lc}
\hline Acceptor & $\begin{array}{c}\text { Relative initial } \\
\text { rate }\end{array}$ \\
\hline D-Fructose & 100 \\
D-Xylulose & 85 \\
L-Sorbose & 16 \\
L-Arabinose & 14 \\
D-Glucose & 0 \\
D-Mannose & 0 \\
D-Galactose & 0 \\
D-Xylose & 0 \\
D-Ribose & 0 \\
\hline
\end{tabular}

Fifty mM each of G-1-P and one of the acceptor sugars listed were incubated with $0.2 \mathrm{U} / \mathrm{ml}$ of the enzyme preparation in $50 \mathrm{mM}$ Tris-maleate buffer (pH 7.0) at $37^{\circ} \mathrm{C}$ for $30 \mathrm{~min}$. The amount of released $\mathrm{Pi}$ was determined as described in MATERIALS AND METHODS. A reaction mixture containing no acceptor sugar was run as a control. The rate with $\mathrm{D}$-fructose was taken as 100.

phosphorylase in the following experiments.

Acceptor specificity of sucrose phosphorylase. Relative initial rates of $\mathrm{Pi}$ release (=disaccharide formation) from G-1-P and one of $\mathrm{D}$-fructose, $\mathrm{D}$-xylulose, $\mathrm{L}$-sorbose and L-arabinose were studied. As summarized in Table 1, the reaction using $\mathrm{D}$-fructose as an acceptor proceeded most rapidly. The reaction using $\mathrm{D}$ xylulose followed, at $85 \%$ as fast as that of sucrose synthesis. Compared with these, the reactions using $\mathrm{L}$-sorbose or $\mathrm{L}$-arabinose as an acceptor proceeded more slowly. D-Glucose, Dmannose, D-galactose, D-xylose and D-ribose did not act at all as an acceptor. These results agree quite well with the data obtained by the partially purified sucrose phosphorylase from $P$. saccharophila, as reviewed by Vandamme et al. ${ }^{17)}$

Synthesis of Glc-Xul by the transfer reaction using G-1-P. Disaccharide synthesis by the transfer reaction using G-1-P and acceptor sugars was studied. The reaction was followed by HPLC. Figure 2 summarizes the results obtained with several acceptors. As is anticipated from Table 1 , sucrose synthesis reached an equilibrium most rapidly, after $1 \mathrm{hr}$ of a reaction, with the maximum yield of about $17 \%$. Then, it began to decrease gradually. Glc-Xul was synthesized at the same rate as that of sucrose synthesis, but the synthesis continued even after the sucrose synthesis leveled off, with the maximum yield of $25 \%$. A maximum yield of about $9 \%$ was obtained in the case of Glc-Sor synthesis. Synthesis of Glc-Ara lasted longer time and its yield reached $18 \%$ after $6 \mathrm{hr}$ and $20 \%$ after $8 \mathrm{hr}$. L-Arabinose is quite unique as an acceptor as it is an aldose and the product formed from it is a reducing disaccharide. Thus $\mathrm{D}$-xylulose was found to be converted into disaccharide with

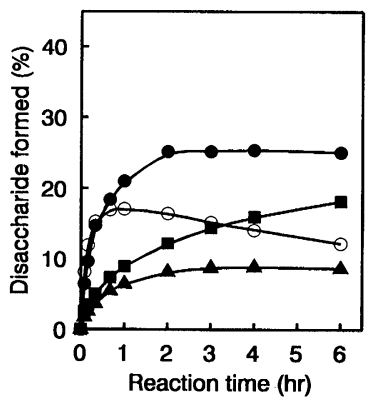

Fig. 2. Time course of disaccharide formation by the transfer reaction from G-1-P and an acceptor sugar.

Fifty $\mathrm{mM}$ each of G-1-P and one of the acceptor sugars were incubated with $8 \mathrm{U} / \mathrm{ml}$ of enzyme preparation in $50 \mathrm{mM}$ Tris-maleate buffer $(\mathrm{pH} 7.0)$ at $37^{\circ} \mathrm{C}$. O, Sucrose ; •, Glc-Xul ; $\Delta$, Glc-Sor ; $\mathbf{\square}$, GlcAra. 


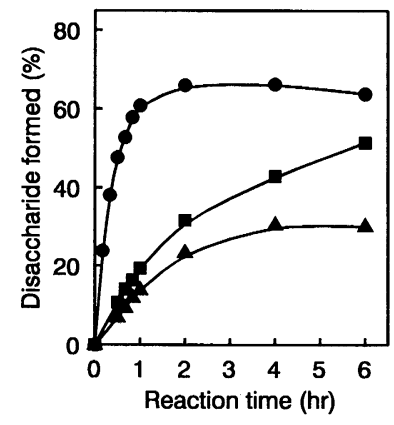

Fig. 3. Time course of disaccharide formation by the transfer reaction from sucrose and an acceptor sugar.

The same conditions as in Fig. 2 were used except that G-1-P was replaced with sucrose. The same symbols were used.

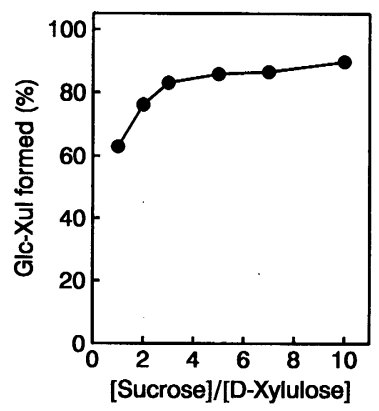

Fig. 4. Effect of molar ratio of sucrose to D-xylulose on the Glc-Xul yield.

Reaction mixtures containing $50 \mathrm{mM}$ D-xylulose and various amounts $(50-500 \mathrm{mM}$ ) of sucrose were incubated with $5.3 \mathrm{U} / \mathrm{ml}$ of enzyme preparation in $50 \mathrm{mM}$ Tris-maleate buffer $(\mathrm{pH} 7.0)$ at $37^{\circ} \mathrm{C}$ for $3 \mathrm{hr}$. The Glc-Xul yield, of each reaction mixture were determined and plotted against the molar ratio.

the highest yield among the tested ketose. However, more than $70 \%$ of added $\mathrm{D}$-xylulose remained unutilized even when the synthesis of Glc-Xul reached an equilibrium in this reaction condition.

Synthesis of Glc-Xul by the transfer reaction using sucrose. Disaccharide synthesis by the transfer reaction using sucrose and acceptor sugars was then studied in a hope to obtain higher yield. Figure 3 summarizes the results of three reactions using $\mathrm{D}$-xylulose, L-sorbose or L-arabinose as an acceptor. Clearly synthesis of Glc-Xul proceeded most rapidly among the three disaccharides and more than $60 \%$ of added

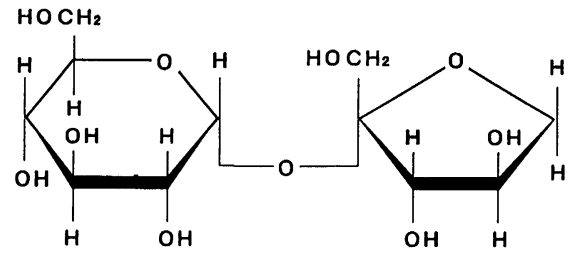

Glc-Xul

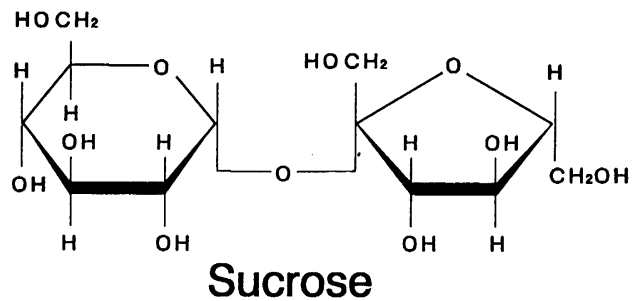

Fig. 5. Structures of sucrose and Glc-Xul.

D-xylulose (or sucrose) was converted into Glc$\mathrm{Xul}$ within $2 \mathrm{hr}$ under the conditions used. Again, transfer to L-arabinose proceeded slowly and progressively through the tested reaction period.

As $\mathrm{D}$-xylulose is much more expensive than sucrose, the molar ratio of sucrose to D-xylulose in the reaction mixture was changed variously and the yields of Glc-Xul were plotted against the molar ratio. Results are shown in Fig. 4. The yield based on added D-xylulose increased from $63 \%$ to $83 \%$ on increasing the molar ratio from 1 to 3 . However, increasing the molar ratio beyond 3 resulted in no more increase in the yield. As described above, a new method was developed which converts Dxylulose into Glc-Xul with an yield as high as $83 \%$.

Glc-Xul is quite close to sucrose in its structure (Fig. 5) ; therefore, it is expected to have similar physicochemical and physiological properties to those of sucrose. However, the presence of a small but distinct difference in their structures may give Glc-Xul some different properties from those of sucrose. Extensive characterization of this disaccharide is of considerable interest from standpoints of both basic research and application.

On the basis of the new efficient method described above, a large-scale production of $\mathrm{Glc}-\mathrm{Xul}$ and its characterization are in progress. 


\section{REFERENCES}

1) M. DOUdOROFF, N. KAPLAN and W. Z. HASSID : J. Biol. Chem., 148, 67-75 (1943).

2) M. Doudoroff, J. M. WAIME and H. WoloCHOW : J. Bacteriol., 57, 423-427 (1949).

3) L. B. TSAI, G. S. GONG and G. T. TsAO : Abstr. Annu. Meet. Am. Soc. Microbiol., K120, 146 (1980).

4) K. BAlASUbramaniAm and P. N. KANNANGARA : J. Natl. Sci. Counc. Sri Lanka, 10, 169-180 (1982).

5) A. A. IMSHENETSKII and T. F. KONDRA T'EVA : Mikrobiologiya, 49, 98-101 (1980).

6) B. O. KAGAN, S. N. LATKER and E. M. ZFASMAN : Biokhimiya, 7, 93-108 (1942).

7) M. DoudorofF, W. Z. HASSID and H. A. BARKER : Science, 100, 315-316 (1944).

8) M. DoudorofF, W. Z. HASSID and H. A. BARKER : J. Biol.Chem., 168, 733-746 (1947).

9) N. J. PAlleroni and M. DoudorofF : J. Biol. Chem., 219, 957-962 (1956).

10) R. Silverstein, J. Voet, D. Reed and R. H. ABELES : J. Biol. Chem., 242, 1338-1346 (1967).

11) J.G. Voet and R.H. Abeles : J.Biol.Chem., 245, 1020-1031 (1970).

12) J. J. MieyAl, M. SimoN and R. H. AbELES : $J$. Biol. Chem., 247, 532-542 (1972).

13) R. WEIMBERG and M. DOUdOROFF : J. Bacteriol., 68, 381-388 (1954).

14) E. J. VANDAMME, J. VAN Loo and A. DE LAPORTE : Biotechnol. Bioeng., 29, 8-15 (1987).

15) G. MiCHAEL : Methods of Enzymatic Analysis, 2 nd ed., Vol. 4, H. U. BERGMEYER, ed., Academic Press, New York, p. 185-191 (1974).

16) O. H. Lowry and J. A. Lopetz : J. Biol. Chem., 162, 421-428 (1946).
17) E. J. VANDAMME, J. VAN LOO, L. MACHTELINCKX and A. DE LAporte : Adv. Appl. Microbiol., 32, 163-201 (1987).

(Received May 11, 1992 ; Accepted August 3, 1992)

$$
\begin{aligned}
& \text { シュクロースホスホリラーゼを用いた } \\
& \text { グルコシルキシルロシドの合成 } \\
& \text { 高橋英樹*, 原 耕三*, 橋本 仁* } \\
& \text { 佐々木 堯**, 谷口 肇**,*** }
\end{aligned}
$$

Leuconostoc mesenteroides 由来のシュクロースホス ホリラーゼ [EC 2.4.1.7] を用い, グルコシルキシルロ

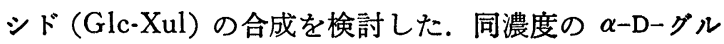
コースー1ーリン酸（G-1-P）と D-キシルロースを用いた 転移反応において，D-キシルロースの約 $25 \%$ が GlcXul に変換された。一方, D-キシルロースの代りに Dーフラクトースを用いたとき，Dーフラクトースの $17 \%$ がショ糖に変換された. 同濃度のショ糖とD-キシル ロースを用いた転移反応に掞いて，Dーキシルロースの 60\% 以上が Glc-Xul に変換された. さらに, D-キシル ロースに対するショ糖のモル比を 3 にあげたとき, 添加 した D-キシルロースの $80 \%$ 以上が Glc-Xul に変換さ れることがわかった. 